\title{
RESEARCH NOTE \\ Effect of water stress on herbicide efficiency applied to Urochloa decumbens
}

\author{
Maria R. Rocha-Pereira ${ }^{1}$, Antônio E. Klar'1, Dagoberto Martins¹, Guilherme \\ S. Ferreira de Souza ${ }^{1}$, and Juana Villalba ${ }^{2}$ \\ ${ }^{1}$ Faculdade de Ciências Agronômicas, Universidade Estadual Paulista (UNESP), Campus de Botucatu. C.P. \\ 237, CEP 18610-307, Botucatu, São Paulo, Brasil. \\ ${ }^{2}$ Facultad de Agronomía, Universidad de la República, Ruta 3 Km 373, CP 60000. Paysandú, Uruguay.
}

\begin{abstract}
M.R. Rocha-Pereira, A.E. Klar, D. Martins, G.S. Ferreira de Souza, and J. Villalba. 2012. Effect of water stress on herbicide efficiency applied to Urochloa decumbens. Cien. Inv. Agr. 39(1): 211-220. This project aimed to measure the control efficiency of Acetil Coenzime A Carboxilase (ACCase)-inhibiting herbicides post-emergence applied to Urochloa decumbens (Stapf) R.D. Webster under different soil water contents. The experiment was conducted in a greenhouse at the Department of Plant Production, Faculty of Agronomic Sciences, UNESP, Botucatu, São Paulo. The experimental design was a completely randomized design with four replications, consisting of a $9 \times 4$ factorial, combined with three water management systems $(-0.03,-0.07$ and $-1.5 \mathrm{MPa})$ and three herbicides (fluazifop-p-butyl, haloxyfop-methyl and sethoxydim + oil using four doses $(100,50,25$ and $0 \%$ of the recommended dose). Herbicide applications were conducted at two vegetative stages for all species: a 4-6 leaf stage and a 2-3 tiller stage. The physiological parameters evaluated were as follows: photosynthetic rate, stomatal conductance, transpiration, leaf temperature and plant dry matter. The visual assessments of phytotoxicity were performed 28 days after herbicide application. The control efficiency was lower in plants grown under soil water potential conditions of $-1.5 \mathrm{MPa}$, regardless of the herbicide used during the two application stages; however, none reached $100 \%$ control. Fractionation of the recommended herbicide doses reduced effectiveness, with the exception of the 50\%-dose application of sethoxydim and fluazifop-p-butyl herbicides, which were also effective in the 4-6 leaf plant control under normal water conditions.
\end{abstract}

Key words: chemical control; graminicide; water restriction; weed.

\section{Introduction}

Urochloa decumbens (Stapf) R.D. Webste is a genus of grass in the Poaceae family (= Gramineae). It is a perennial species that is considered an excellent forage producer with high-quality

Received May 20, 2010. Accepted November 21, 2011. Corresponding author: mariarenata10@hotmail.com foliage and resistance to grazing and trampling, thus preventing soil erosion (Lorenzi, 2000). It is a very competitive species in soybean crops in central-western Brazil and in sugar cane crops in the State of São Paulo (Merotto Junior et al., 1997).

Urochloa decumbens has a high survival rate in disturbed soils, high growth rate, drought 
resistance and high exploration capacity for soil nutrients, among other characteristics (Grime, 1982), which makes this species well adapted to agricultural environments, resulting in competitive advantages over cultivated plants.

According to Merotto Junior et al. (1997), although chemical weed control has been recommended because of its efficiency, speed and cost effectiveness, herbicide effectiveness is variable and dependent on environmental conditions at the time of application, weed control and state of development. An important factor to consider regarding chemical control is the weed development state at the time of application because this eventually will generate different responses (Rizzardi and Fleck, 2004; Carvalho et al., 2006). These same authors found that the control success in species such as Amaranthus spp., Bidens spp. and Sida rhombifolia was determined by the degree of weed growth, reinforcing the hypothesis that applications should occur during initial development stages.

According to Rodrigues (1994), the primary action mode of grass herbicides is the inhibition of fatty acid synthesis by inhibiting the enzyme acetyl coenzyme-A carboxyl (ACCase), which is present in grasses and is highly sensitive to these herbicides.

Environmental stresses, such as high temperatures and water restriction, can interfere with the absorption of herbicides by increasing the thickness of the cuticle or contributing to the evaporation of water droplets and volatilization of the products applied. Water stress also affects the physiology, morphology and developmental processes in plants, which reduces photosynthesis due to stomatal closure and causes leaf senescence (Jones, 1985).

According to Abbott and Sterling (2006), herbicide effectiveness is jeopardized by reduced water availability in the environment, which affects absorption, translocation and metabolism. Ac- cording to Deuba (1992), the amount of herbicide that penetrates the leaf cuticle of weeds is affected by conditions such as soil moisture, herbicide characteristics and developmental state of the weed. Corroborating these data, Pereira et al. (2011) found that the control effectiveness of Eleusine indica using the herbicide sethoxydim was lower in plants grown under water deficit conditions.

Aside from the effect of low water availability in herbicide control efficacy, applying different doses of the same herbicide may produce different outcomes regarding weed control when applied to plants that grow in the absence of water. However, Pereira et al. (2010) found no differences in the control of $U$. plantaginea between applications of 50 and $100 \%$ of the recommended dose of fluazifop-p-butyl, haloxyfop-methyl and sethoxydim; $50 \%$ of the dose of these herbicides was effective enough to control this weed.

Due to the importance of $U$. decumbens and other grass weeds, further studies and the continued development of more rigorous evaluation methodologies of environmental effects, such as water stress on herbicide effectiveness, is necessary. There are few research studies in the international literature that address this topic; for example, the extant studies are based on other weed species (Pereira, 2010 and 2011).

The objective of this work was to study the effect of different conditions of water stress on the control effectiveness of inhibiting herbicides, such as ACCase, applied during post-emergence at two developmental stages of $U$. decumbens.

\section{Materials and methods}

This study was conducted in a greenhouse at the Department of Plant Production, Agricultural Sector of the Faculty of Agronomic Sciences, UNESP, Botucatu - São Paulo, whose geographi- 
cal coordinates are $22^{\circ} 51^{\prime} 03$ ' latitude south and $48^{\circ} 25^{\prime} 37^{\prime \prime}$ longitude west, with an altitude of $786 \mathrm{~m}$.

During the experimental period (August to November, 2008), the minimum temperature in the greenhouse was $17.1^{\circ} \mathrm{C}$, the maximum temperature was $25^{\circ} \mathrm{C}$, the relative humidity was $54.6 \%$, and evapotranspiration, which was monitored daily using a Class A Tank was $4.16 \mathrm{~mm} \mathrm{month}^{-1}$.

Planting was performed in $2 \mathrm{~L}$ plastic containers using soil classified as medium (65.6\% sand, $6.7 \%$ silt and $27.7 \%$ clay) according to particle size analysis performed by the soil laboratory in the Department of Soil Science at Estadual Paulista University. Fertilization was performed with $200 \mathrm{~kg} \mathrm{ha}^{-1}$ NPK fertilizer of an 8:28:16 formulation according to the chemical analysis (Table 1) and the recommendation of the Brazilian company Pesquisa Agropecuaria (EMBRAPA) for the cultivation of corn.

Before planting, the soil was air dried to a constant weight to obtain the water retention curve using a Richards' pressure plate (Klar, 1984). From the results of the retention curve, the following three minimum water potentials were established

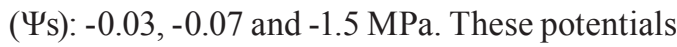
correspond to 13,10 and $8 \%$ of the soil moisture, respectively, which were the water management systems achieved through plastic container weighting; $0.03 \mathrm{MPa}$ was determined to be the proper soil moisture condition for plant growth.

After obtaining a defined potential for each treatment, the water lost by evapotranspiration was replaced to reach the mass of the maximum water potential of soil water retention $(-0.01$ $\mathrm{MPa} / 14 \%$ soil moisture). Water management was initiated when plants reached the two-leaf development stage.

The application of herbicide treatments was performed using back spray equipment, equipped with four XR11002VS flat fan nozzles that were spaced $50 \mathrm{~cm}$ apart with a pressure of $200 \mathrm{kPa}$ and that were calibrated for an application of $200 \mathrm{~L} \mathrm{ha}^{-1}$.

The herbicides were applied during two weed stages of development (4-6 leaf and 2-3 tiller stages); the application times comprised two independent experiments. The experimental design used in this research was completely randomized with four replications. Each experiment treatment was arranged in a $9 \mathrm{x} 4$ factorial; the first factor was composed of nine combinations: three herbicides (fluazifop-pbutyl, haloxyfop-methyl and sethoxydim) and three water management systems ( $\Psi \mathrm{s})$; the second factor corresponded to four doses of each herbicide ( 0 , 25,50 and $100 \%$ of the recommended dose). According to the manufacturers of each commercial product, $100 \%$ of the recommended dose of each herbicide is $184 \mathrm{~g}$ a.i. ha ${ }^{-1}$ for sethoxydim, $60 \mathrm{~g}$ a.i. ha ${ }^{-1}$ for haloxyfop-methyl and $125 \mathrm{~g}$ a.i. ha ${ }^{-1}$ for fluazifop-p-butyl. For sethoxydim, adding an adjuvant to $1 \%$ of the volume of application was recommended, which consisted of a mineral oil.

The evaluated physiological characteristics, such as the photosynthetic rate, stomatal conductance, transpiration and leaf temperature, were measured using an infrared gas analyzer (IRGA Licor Li6400 ) in 2-3 tiller stage plants due to their larger

Table 1. Chemical analysis of soil used in the study. Botucatu/SP, 2008.

\begin{tabular}{lccccccccc}
\hline $\mathrm{pH}$ & D.M. & P resin & \multicolumn{4}{c}{$\mathrm{mmol} \mathrm{dm}^{-3}$} \\
$\mathrm{CaCl}_{2}$ & $\mathrm{~g} \mathrm{dm}^{-3}$ & $\mathrm{mg} \mathrm{dm}^{-3}$ & $\mathrm{H}+\mathrm{Al}$ & $\mathrm{K}$ & $\mathrm{Ca}$ & $\mathrm{Mg}$ & $\mathrm{SB}$ & $\mathrm{CEC}$ & $(\%)$ \\
\hline 4.6 & 7 & 3 & 22 & 0.2 & 2 & 2 & 4 & 26 & 15 \\
\hline
\end{tabular}

$\mathrm{P}$ resin: phosphorus extraction method for use of the resin.

SB: sum of bases.

CEC: cation exchange capacity.

$\mathrm{V} \%$ : percentage of base saturation. 
size. The evaluations were performed between 8:00 and 10:00 am in the plants with different water management systems and without herbicide application to characterize the physiological condition of plants under different water treatments.

It was not possible to perform these measurements in the 4-6 leaf stage due to the difficulty of equipment insertion in plants with small leaves and also due to the high degree of necrosis and small size of the treated plants.

The treatment effects on the plants were visually evaluated at 7, 14, 21 and 28 days after application (DAA), depending on the development stage, using a percentage scale of grades in which " 0 " was damage absence and "100" was regarded as plant death (SBCPD, 1995). At the end of the evaluations, the plants were collected and dried in a forced air oven at $60^{\circ} \mathrm{C}$ until reaching constant weight to evaluate the dry matter.

The results of the physiological and phytotoxicity parameters were subjected to an analysis of variance for the " $F$ " test and plant dry matter was subjected to the linear and polynomial regression models; the treatment means were compared using Tukey's test at the 5\% probability level.

\section{Results and discussion}

Table 2 presents the herbicide results 28 days postapplication in the 4-6 leaf stage. A $100 \%$ dose of the recommended herbicides, sethoxydim and haloxyfop-methyl, showed a 90\% control in plants without water stress (13\% soil moisture), while the herbicide fluazifop-p-butyl controlled only $70 \%$. With $10 \%$ moisture in the soil, the performance was lower but followed a similar trend. Better controls were obtained with the application of herbicides sethoxydim and haloxyfop-methyl (equal to and greater than $84 \%$ ), while for the herbicide fluazifop-p-butyl the control that was obtained was close to $50 \%$.

Less control was observed in plants growing in $8 \%$ soil moisture, specifically approximately $80 \%$ for sethoxydim and haloxyfop and $43 \%$ for fluazifop-p-butyl.

The lowest control percentage occurred in plants with a water deficit, which can be attributed to

Table 2. Percentage of control plants of $U$. decumbens in the 4-6 leaf stage under different water management systems, 28 days after herbicide application. Botucatu/SP, 2008.

\begin{tabular}{|c|c|c|c|c|c|c|c|c|c|}
\hline \multirow{3}{*}{$\begin{array}{l}\text { Treatment } \\
\text { Herbicides } \\
\text { Sethoxydim }\end{array}$} & \multirow{3}{*}{$\begin{array}{l}\text { Water management, \% } \\
13\end{array}$} & \multicolumn{8}{|c|}{ Herbicide dose, $\%$} \\
\hline & & \multicolumn{2}{|c|}{0} & \multicolumn{2}{|c|}{25} & \multicolumn{2}{|c|}{50} & \multicolumn{2}{|c|}{100} \\
\hline & & 0.00 & $\mathrm{aC}$ & 53.70 & $\mathrm{aB}$ & 84.20 & $\mathrm{aA}$ & 93.50 & $\mathrm{aA}$ \\
\hline & 10 & 0.00 & $\mathrm{aD}$ & 31.00 & $\mathrm{bcC}$ & 55.00 & $\mathrm{bB}$ & 84.00 & $\mathrm{abA}$ \\
\hline & 8 & 0.00 & $\mathrm{aC}$ & 7.50 & $\mathrm{deC}$ & 57.50 & $\mathrm{bB}$ & 78.20 & $\mathrm{abA}$ \\
\hline \multirow[t]{3}{*}{ Haloxyfop-methyl } & 13 & 0.00 & $\mathrm{aD}$ & 35.00 & $\mathrm{abC}$ & 61.20 & $\mathrm{bB}$ & 92.50 & $\mathrm{aA}$ \\
\hline & 10 & 0.00 & $\mathrm{aD}$ & 29.20 & $\mathrm{bcC}$ & 58.70 & $\mathrm{bB}$ & 89.00 & $\mathrm{abA}$ \\
\hline & 8 & 0.00 & $\mathrm{aC}$ & 11.70 & $\mathrm{cdeC}$ & 49.50 & $\mathrm{bB}$ & 80.00 & $\mathrm{abA}$ \\
\hline \multirow[t]{3}{*}{ Fluazifop-p-butyl } & 13 & 0.00 & $\mathrm{aC}$ & 26.70 & bcdB & 67.50 & $\mathrm{abA}$ & 70.00 & $\mathrm{bcA}$ \\
\hline & 10 & 0.00 & $\mathrm{aB}$ & 5.00 & $\mathrm{eB}$ & 7.00 & $\mathrm{cB}$ & 52.00 & $\operatorname{cd} A$ \\
\hline & 8 & 0.00 & $\mathrm{aB}$ & 2.25 & $\mathrm{eB}$ & 4.50 & $\mathrm{cB}$ & 43.20 & $\mathrm{dA}$ \\
\hline $\mathrm{F}_{\text {treatment }}(\mathrm{T})$ & $38.38^{* *}$ & & & & & & & & \\
\hline $\mathrm{F}_{\text {doses }}(\mathrm{D})$ & $443.5 * *$ & & & & & & & & \\
\hline$F(T) \times(D)$ & $7.18^{* *}$ & & & & & & & & \\
\hline CV (\%) & 25.4 & & & & & & & & \\
\hline
\end{tabular}

Means followed by the same lowercase letter in the column and capital letter in line do not differ according to Tukey's test $(\mathrm{P} \leq 0.01)$.

$* *$ Significant at $1 \%$ probability. 
stress resistance strategies, such as cuticle thickening, lower transpiration and reduced leaf area (Taiz and Zeiger, 2002; Herrero and Johnson, 1981; Carlesso, 1993).

In applications using 50 and $100 \%$ of the dose of sethoxydim and fluazifop-p-butyl, no control differences were observed when the plants were without water stress ( $13 \%$ water management), whereas with the herbicide haloxyfop- methyl, a decrease in control was observed when using the lower applied dose independently of water management. In addition, an efficiency reduction was observed with reduced doses of the herbicides sethoxydim and fluazifop-p-butyl in plants under water stress (10 and $8 \%$, respectively). The implementation of $25 \%$ of all recommended herbicides adversely affected the control effectiveness in all plants regardless of water management.

In the treatments without herbicides and with soil moisture at $13 \%$, the highest dry matter values were obtained compared to the dry matter of plants subjected to water management systems of 10 and $8 \%$, respectively (Figure 1). This result may be one of the factors responsible for the increased phytotoxicity observed in treatments without water restriction because a greater leaf area may have resulted in an increased interception of the products.

With the application of the herbicide fluazifopp-butyl in plants with at least $8 \%$ moisture, no differences were observed between the applied doses. By comparing the dry matter of plants subjected to $13 \%$ water management with an herbicide application of $25 \%$ of the recommended dose, as well as with a control without herbicide application, a reduction of dry matter was observed.

Among the dry matter result of plants with different herbicide dose applications, important differences were observed in the treatments with 25 and 50\% of the herbicide recommended dose compared to $100 \%$ of the dose, which at 28 DAA provided the lowest values of dry matter independently of the water management system that was used.
In treatments with $10 \%$ moisture and herbicide application at all doses, more plant dry matter was observed. This result can be explained by the greater control in plants without water stress (13\% water management) as well as by the severe water restriction imposed on plants with $8 \%$ water management, resulting in lower growth and development. Such behavior (higher values of dry matter) was observed with the use of other herbicides in plants that were subjected to $10 \%$ water management (Figure $1 \mathrm{~A}, \mathrm{~B}, \mathrm{C}$ ).

It was observed that plants treated with haloxyfopmethyl and subjected to $8 \%$ water management maintained their dry matter production regardless of the herbicide dose used, observing the greatest accumulation when using $100 \%$ of the dose. In plants under these same management conditions, i.e., using sethoxydim, a decrease in the values of dry matter was observed after increasing the product doses.

When plants are subjected to water deficits, conflicts can be observed between water conservation and the $\mathrm{CO}_{2}$ assimilation rate to produce carbohydrates (Taiz and Zeiger, 2002). In addition, the greater the atmosphere demand is, the greater the need will be for water flow in the soil-plant-atmosphere system and in situations where water is not available; thus, plants turn to stomatal closure to prevent loss water (Santos and Carlesso, 1998), making impossible the entry of the herbicide through them and reducing the control effectiveness.

At the 28 DAA 2-3 tiller stage, the maximum control achieved with the sethoxydim treatment, $13 \%$ water management and $100 \%$ of the herbicide dose was $89 \%$ (Table 3). The haloxyfop-methyl applications presented the best results in plants growing in soils with $10 \%$ moisture at a $100 \%$ dose. Furthermore, the herbicide fluazifop-p-butyl presented the lowest percentages of control; its best result was $72 \%$ with $13 \%$ water management and at a $100 \%$ dose.

From these results, it can be concluded that $U$. decumbens plants under water stress of $-1.5 \mathrm{MPa}$ 

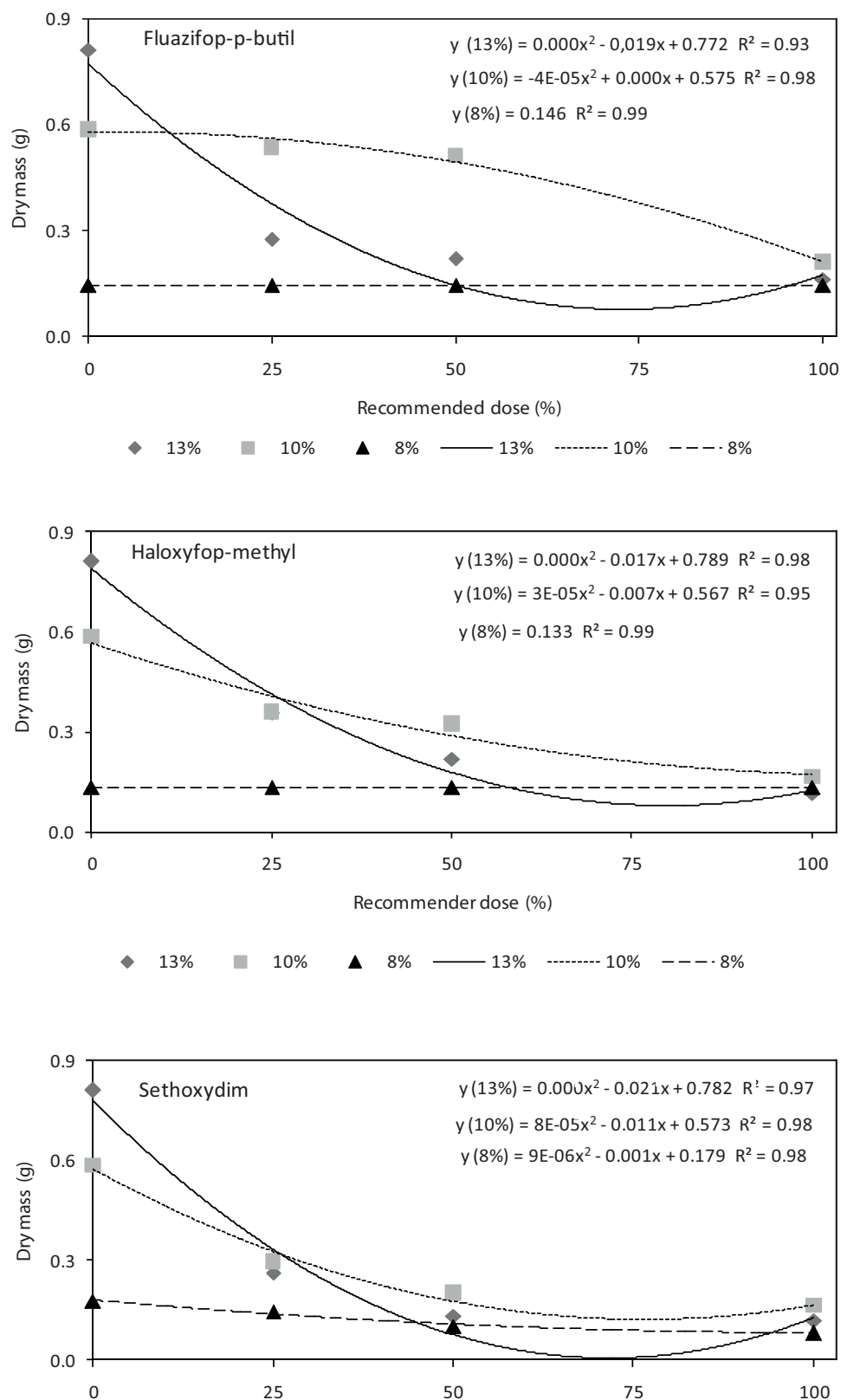

Figure 1. Dry mass of plants of $U$. decumbens under different water management systems with herbicide applications of four different doses, after 28 days on plants at the first application stage (4-6 leaves); $\mathrm{n}=4$; Botucatu/SP, 2008.

were difficult to control and that the control provided by the different herbicides for plants growing in soil with 13 and $10 \%$ moisture was similar.

In treatments without herbicides, reduced dry matter was actually lower in plants without water stress ( $13 \%$ water management) when compared to the water management systems of 10 and $8 \%$ moisture (Figure 1). The above results are comparable to those obtained by Cruz et al. (2009) in studies with cultivars of the Urochloa brizantha species; they described that water deficit reduced the stretching and growth of the plant. 
Table 3. Percentage of control plants of $U$. decumbens in the 2-3 tiller stage under different water managements systems, 28 days after herbicide application. Botucatu/SP, 2008.

\begin{tabular}{|c|c|c|c|c|c|c|c|c|c|}
\hline \multirow{2}{*}{$\begin{array}{l}\text { Treatment } \\
\text { Herbicides }\end{array}$} & & \multicolumn{8}{|c|}{ Herbicide dose, $\%$} \\
\hline & Water management, $\%$ & \multicolumn{2}{|c|}{0} & \multicolumn{2}{|c|}{25} & \multicolumn{2}{|c|}{50} & \multicolumn{2}{|c|}{100} \\
\hline & 13 & 0.00 & $\mathrm{aC}$ & 9.00 & $\mathrm{abBC}$ & 17.20 & $\mathrm{cB}$ & 89.00 & $\mathrm{aA}$ \\
\hline \multirow[t]{3}{*}{ Sethoxydim } & 10 & 0.00 & $\mathrm{aC}$ & 8.00 & $\mathrm{abC}$ & 26.70 & $\mathrm{abcB}$ & 67.50 & $\mathrm{bcA}$ \\
\hline & 8 & 0.00 & $\mathrm{aC}$ & 7.70 & $\mathrm{abBC}$ & 16.70 & $\mathrm{cB}$ & 60.50 & $\mathrm{bcA}$ \\
\hline & 13 & 0.00 & $\mathrm{aC}$ & 6.20 & $\mathrm{abC}$ & 25.00 & $\mathrm{abcB}$ & 71.20 & $\mathrm{bA}$ \\
\hline \multirow[t]{3}{*}{ Haloxyfop-methyl } & 10 & 0.00 & $\mathrm{aD}$ & 13.50 & $\mathrm{abC}$ & 35.00 & $a b B$ & 85.00 & $\mathrm{aA}$ \\
\hline & 8 & 0.00 & $\mathrm{aD}$ & 15.50 & $\mathrm{aC}$ & 36.20 & $\mathrm{aB}$ & 64.50 & $\mathrm{bcA}$ \\
\hline & 13 & 0.00 & $\mathrm{aC}$ & 0.00 & $\mathrm{bC}$ & 20.70 & $\mathrm{cB}$ & 72.50 & $\mathrm{bA}$ \\
\hline \multirow[t]{2}{*}{ Fluazifop-p-butyl } & 10 & 0.00 & $\mathrm{aC}$ & 0.00 & $\mathrm{bC}$ & 22.00 & $\mathrm{bcB}$ & 42.50 & $\mathrm{dA}$ \\
\hline & 8 & 0.00 & $\mathrm{aC}$ & 0.00 & $\mathrm{bC}$ & 19.50 & $\mathrm{cB}$ & 53.70 & $\operatorname{cdA}$ \\
\hline $\mathrm{F}_{\text {treatment }}(\mathrm{T})$ & $15.03 * *$ & & & & & & & & \\
\hline $\mathrm{F}_{\text {doses }}(\mathrm{D})$ & $717.5^{* *}$ & & & & & & & & \\
\hline$F(T) \times(D)$ & $5.96^{* *}$ & & & & & & & & \\
\hline CV (\%) & 26.9 & & & & & & & & \\
\hline
\end{tabular}

Means followed by the same lowercase letter in the column and capital letter in line do not differ according to Tukey's test $(\mathrm{P} \leq 0.01)$.

**Significant at $1 \%$ probability.

It was observed that the dry matter of plants that were grown the longest on an established water regime (2-3 tiller stage application) presented different behaviors, depending on the management system to which they were subjected, in treatments with herbicide application (Figure 2). The behavior of the dry matter of plants with herbicides sethoxydim and haloxyfop-methyl was similar; this behavior decreased as the herbicides doses increased and as the soil water potential decreased.

The photosynthesis rate is directly related to transpiration and stomatal conductance of plants (Machado and Lagoa, 1994), which is something confirmed by this study (Table 4). Increases in photosynthetic rates associated with increases in transpiration were estimated as the fluid restriction in plants was reduced. The transpiration rate in plants that were subjected to 10 and $8 \%$ water management was reduced by 32 and $48 \%$, respectively, compared to plants with $13 \%$ water management.

While working with corn, Pereira et al. (2003) found a general trend of decreased photosynthe- sis as plant water decreased; photosynthesis was reduced to values close to zero with soil water values below $-1.5 \mathrm{MPa}$.

Corroborating the results of the photosynthetic rate, greater transpiration rates in plants without water stress were observed on average $50 \%$ higher than in plants growing in soils with $-1.5 \mathrm{MPa}(8 \%$ water management) and $31 \%$ higher compared to those maintained at a tension of $-0.07 \mathrm{MPa}(10 \%$ water management). Stomatal conductance showed the same pattern, i.e., higher in treatments without water restriction. The limited availability of water creates a reduction in stomatal conductance, resulting in decreased gas exchange as the access to $\mathrm{CO}_{2}$ of the photosynthetic apparatus decreases, limiting photosynthesis.

The difference in environment temperature and leaf temperature reached $8.2^{\circ} \mathrm{C}$ in plants subjected to $8 \%$ water management and $4.6^{\circ} \mathrm{C}$ in plants maintained to a minimum of $-0.03 \mathrm{MPa}$ ( $13 \%$ water management). No statistically significant differences were observed between the water management systems of 10 and $13 \%$. 

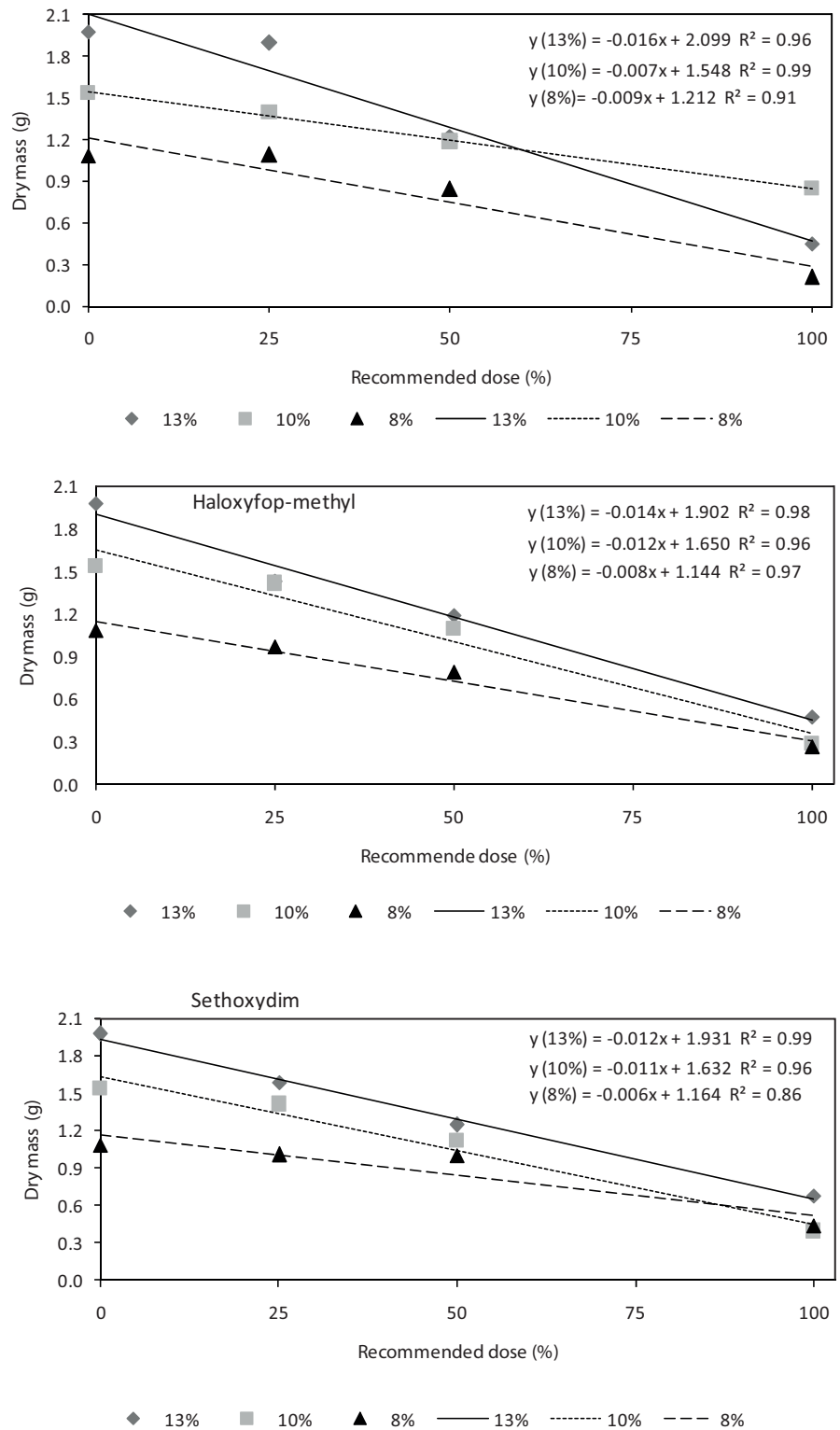

Figure 2. Dry mass of plants of $U$. decumbens under different water management systems with herbicide applications of four different doses, after 28 days on plants at the second stage (2-3 tillers); $n=4$; Botucatu/SP, 2008.

The transpiration and photosynthetic rates were found to be directly related to stomatal conductance. Plants without water stress transpire more due to increased stomatal opening, which is inversely proportional to leaf temperature; with increased perspiration, the leaf temperatures decrease. Coinciding with these results, Pereira et al. (2011) described that the rate of photosynthesis, transpiration and stomatal conductance were higher in Eleusine indica plants kept without water stress (only with the potential of $-0.03 \mathrm{MPa}$ ), which presented the lowest leaf temperatures compared to the environment and, consequently, presented higher dry matter and higher values of phytotoxicity with the application of the herbicide sethoxydim.

The results of phytotoxicity observed in this study may be related to physiological parameters evaluated because the plants under water stress 
Table 4. Photosynthetic rate $\left(\mu \mathrm{mol} \mathrm{m} \mathrm{m}^{-2} \mathrm{~s}^{-1}\right)$, transpiration $\left(\mathrm{mol}\left(\mathrm{H}_{2} \mathrm{O}\right) \mathrm{m}^{-2} \mathrm{~s}^{-1}\right)$, stomatal conductance $\left(\mathrm{mmol} \mathrm{m} \mathrm{m}^{-2} \mathrm{~s}^{-1}\right)$ and air - plant leaf temperature difference $\left({ }^{\circ} \mathrm{C}\right)$ of $U$. decumbens maintained at different soil moisture conditions. Botucatu/SP, 2008 .

\begin{tabular}{lcccc}
\hline Water management, $\%$ & Photosynthetic rate & Transpiration & Stomatal conductance & T air - T leaf \\
\hline 13 & $28.75 \mathrm{a}$ & $2.476 \mathrm{a}$ & $0.0595 \mathrm{a}$ & $4.6 \mathrm{~b}$ \\
10 & $18.45 \mathrm{~b}$ & $1.69 \mathrm{~b}$ & $0.0444 \mathrm{~b}$ & $6.3 \mathrm{~b}$ \\
8 & $13.74 \mathrm{~b}$ & $1.304 \mathrm{c}$ & $0.034 \mathrm{c}$ & $8.2 \mathrm{a}$ \\
$\mathrm{F}_{\text {treatment }}(\mathrm{T})$ & $15.14^{* *}$ & $68.343^{* *}$ & $30.786^{* *}$ & $15.901^{* *}$ \\
$\mathrm{CV}(\%)$ & 19.41 & 7.85 & 9.94 & 30.98 \\
d.m.s. & 7.7931 & 0.2853 & 0.0094 & 2.8985 \\
\hline
\end{tabular}

Means followed by the same lowercase letter in the column do not differ according to Tukey's test $(\mathrm{P} \leq 0.01)$.

**Significant at $1 \%$ probability.

(with only a minimum of $8 \%$ moisture) had lower rates of photosynthesis, transpiration, stomatal conductance and phytotoxicity.

It can be concluded in this study that the effectiveness of herbicide control in $U$. decumbens was influenced by water management; the water potential of $8 \%$ was the most damaging to herbicide performance.
The fluazifop-p-butyl herbicide showed less control in all water management systems in the two plant stages studied.

The plants without water stress were better controlled until the four-leaf stage and the application of a $50 \%$ dose of the herbicides sethoxydim and fluazifop-p-butyl was effective in controlling plants with 4-6 leaves under normal water conditions.

\section{Resumen}

M.R. Rocha-Pereira, A.E. Klar, D. Martins, G.S. Ferreira de Souza y J. Villalba. 2012. Efecto del estrés hídrico sobre la eficacia de los herbicidas aplicados en Urochloa decumbens. Cien. Inv. Agr. 39(1): 211-220. El objetivo del trabajo fue relacionar la eficacia del control de los herbicidas aplicados ACCase inhibición de post-emergencia en Urochloa decumbens bajo diferentes contenidos de agua. El ensayo se realizó en un invernadero en el Departamento de Producción Vegetal, Facultad de Ciencias Agronómicas, UNESP, Botucatu, São Paulo. El diseño experimental fue completamente aleatorizado con 4 repeticiones, consistió en un factorial 9x4, con la combinación de tres sistemas de manejo de agua $(-0,03,-0,07$ y $-1,5 \mathrm{MPa})$ con tres herbicidas (fluazifop-p -butilo, haloxifop-metilo y setoxidim + aceite Assist) y cuatro dosis de $(100,50,25$ y $0 \%$ de la dosis recomendada). La aplicación de los herbicidas se realizó en dos estadios de desarrollo, 4-6 hojas y 2-3 macollos. Los parámetros fisiológicos evaluados fueron: tasa de fotosíntesis, conductancia estomática, transpiración, temperatura de las hojas y la materia seca de las plantas. Las evaluaciones visuales de fitotoxicidad se realizaron a los 28 días después de la aplicación. La eficacia de control fue menor en las plantas con un potencial hídrico de -1,5 MPa, independientemente del herbicida utilizado en los dos momentos de aplicación. El fraccionamiento de la dosis recomendada de herbicidas reduce la eficacia, con excepción de la aplicación del 50\% de la dosis de los herbicidas setoxidim y fluazifop-p-butil, que lograron una eficacia en el control de las plantas con 4-6 hojas, en condiciones hídricas normales.

Palabras clave: Control químico, graminicida, malezas, restricción hídrica. 


\section{References}

Abbott, L.B., and T.M. Sterling. 2006. Recovery of African rue seedlings from water stress: Implications for recruitment and invasion. African rue (Peganum harmala) seedling response to herbicides applied under water-deficit stress. Weed Science 54:198-204.

Carlesso, R. 1993. Influence of soil water deficits on maize growth and leaf area adjustments. Ph. D. Thesis. Michigan State University. Michigan, United States of America. 268 pp.

Carvalho, S.J.P., J.A.R. Buissa, M. Nicolai, R.F. López-Ovejero, and P.J. Christoffoleti. 2006. Suscetibilidade diferencial de plantas daninhas do gênero Amaranthus aos herbicidas trifloxysulfuron-sodium e chlorimuron-ethyl. Planta daninha 24:541-548.

Cruz, P.G., P.M. Santos, J. Altoé, e C.B. Valle. 2009. Tolerância ao déficit hídrico em cultivares e/ou acesso de Brachiaria brizantha Stapf: alongamento foliar. 46 Reunião Anual da Sociedade Brasileira de Zootecnia. Maringá, Brasil (Anais). p. 46.

Deuber, R. 1992. Ciências das plantas daninhas: fundamentos. Primeira edição. FUNEP. Jaboticabal, Brasil. 431 pp.

Grime, J. P. 1982. Estratégias de adaptación de las plantas y procesos que controlan la vegetación. Segunda edición. Editorial Limusa, Mexico. 291 pp.

Herrero, M.P., and R.R. Johnson. 1981. Drought stress and its effects on maize reproductive systems. Agronomy Journal 21:105-110.

Jones, C.A. 1985. C4 grasses and cereals: growth, development and stress response. First edition. John Wiley \& Sons. New York, USA. 419 pp.

Klar, A. E. 1984. A água no sistema solo-planta-atmosfera. Segunda edição. Editora Nobel. São Paulo, Brasil. 408 pp.

Lorenzi, H. 2000. Plantas daninhas do Brasil: terrestres, aquáticas, parasitas e tóxicas. Terceira edição. Editora Plantarum. Nova Odessa, Brasil. $624 \mathrm{pp}$.
Machado, E.C., and A.M.M.A. Lagôa. 1994. Trocas gasosas e condutância estomática em três espécies de gramíneas. Bragantia 53:141-149.

Merotto Junior, A., M.L. Almeida, and O. Fuchs. 1997. Aumento do rendimento de grãos de milho através do aumento da população de plantas. Ciência Rural 27:549-554.

Pereira, M.R.R., D. Martins, J.I.C. Silva, A.C.P. Rodrigues-Costa, and A.E. Klar. 2010. Efeito de herbicidas sobre plantas de Brachiaria plantaginea submetidas a estresse hídrico. Planta Daninha 28:1047-1058.

Pereira, M.R.R., G.S.F. Souza, D. Martins, A.L. Melhorança Filho, and A.E. Klar. 2011. Respostas de plantas de Eleusine indica sob diferentes condições hídricas a herbicidas inibidores da ACCase. Planta daninha 29:397-404.

Pereira, P.G., J.I. Bergonci, H. Bergamaschi, L.M.G. Rosa, e S. França. 2003. Efeitos de diferentes níveis de déficit hídrico na fotossíntese e condutância foliar em milho. Revista Brasileira de Agrometeorologia 11:53-62.

Rizzardi, M.A., and N.G. Fleck. 2004. Dose econômica de acifluorfen + bentazon para controle de picão preto e guanxuma em soja. Planta daninha 22:117-125.

Rodrigues, J.D. 1994. Absorção, translocação e modo de ação de defensivos. Primeira edição. UNESP, Instituto de Biociências, Botucatu, Brasil. $106 \mathrm{pp}$.

Santos, R.F., and R. Carlesso. 1998. Déficit hídrico e os processos morfológicos e fisiológicos das plantas. Revista Brasileira de Engenharia Agrícola e Ambiental 2:287-294.

SBCPD. 1995. Procedimentos para instalação, avaliação e analise de experimentos com herbicidas. Sociedade Brasileira da Ciência das Plantas Daninhas (SBCPD). Londrina, Brasil. 42 pp.

Taiz, L., and E. Zeiger. 2002. Fisiologia vegetal. Terceira edição. Editora Artmed. São Paulo, Brasil. 719 pp. 